\title{
The attitude of nursing staff towards the death and dying of the patient
}

Postawy personelu pielęgniarskiego wobec śmierci i umierania pacjenta

\section{Dawid Makowicz', Renata Dziubaszewska', Natalia Makowicz², Patrycja Barna³, Monika Piękoś ${ }^{3}$}

'Państwowa Wyższa Szkoła Zawodowa im. Stanisława Pigonia w Krośnie/ State Higher Vocational School in Krosno

${ }^{2}$ Wojewódzki Szpital Podkarpacki im. Jana Pawła II w Krośnie/ John Paul II Memorial Subcarpathian Voivodeship Hospital in Krosno

${ }^{3}$ Studenckie Koło Honorowych Dawców Krwi i Potencjalnych Dawców Szpiku, Państwowa Wyższa Szkoła Zawodowa im. Stanisława Pigonia w Krośnie/ Student Association of Voluntary Blood Donors and Potential Bone Marrow Donors, State Higher Vocational School in Krosno

CORRESPONDING AUTHOR/AUTOR DO KORESPONDENCJ:

Renata Dziubaszewska

Państwowa Wyższa Szkoła Zawodowa im. Stanisława Pigonia w Krośnie

ul. Rynek 1, 38-400 Krosno

e-mail: renata.rabiasz@wp.pl

STRESZCZENIE

Słowa kluczowe:

ABSTRACT

Key words:

\section{POSTAWY PERSONELU PIELEGNIARSKIEGO WOBEC SMMERCI I UMIERANIA PACJENTA}

Wstęp. W pracy zawodowej członkowie zespołów pielęgniarskich częściej niż inne grupy zawodowe mają styczność ze śmiercią człowieka. Śmierć jest źródłem wielu negatywnych emocji, mogących powodować zwiększone narażenie na wypalenie zawodowe. Dlatego niezwykle ważne jest by personel pielęgniarski cechował się racjonalnym podejściem do umierających pacjentów, które pozwoli im na sprawowanie najbardziej optymalnej opieki nad chorymi w końcowym okresie ich życia.

Cel. Ocena postaw personelu pielęgniarskiego wobec umierania i śmierci pacjenta.

Materiał i metody. Badanie zostało przeprowadzone za pomocą metody sondażu diagnostycznego z wykorzystaniem autorskiego kwestionariusza ankiety składającego się łącznie z 40 pytań, w tym 26 jednokrotnego i 4 wielokrotnego wyboru oraz 10 pytań metryczki. Materiał do badania został zebrany w marcu i kwietniu 2018 r., zbadano opinię 581 pielęgniarek i 13 pielęgniarzy pracujących na oddziałach szpitalnych, gdzie personel pielęgniarski ma częsty kontakt z pacjentami umierającymi. Analiza została przeprowadzona za pomocą programu SPSS.

Wyniki. Personel pielęgniarski w największym stopniu (52,2\%) rozumie śmierć jako naturalne zjawisko, z którym musi spotkać się każdy człowiek. W większości pielęgniarki i pielęgniarze do śmierci pacjenta podchodzą emocjonalnie (42,3\%). Najczęstszymi emocjami zespołów pielęgniarskich towarzyszących śmieci pacjenta są współczucie $(69,4 \%)$ oraz smutek $(67,8 \%)$. Personel pielęgniarski za najbardziej etyczne postępowanie wobec umierającego pacjenta uważa zapewnie mu godnych warunków umierania (98\%). Pielęgniarki i pielęgniarze uporczywą terapię w 79,6\% uznają za przedłużanie cierpienia.

Wnioski. Pielęgniarki i pielęgniarze w kontakcie z pacjentem umierającym najczęściej odczuwają współczucie oraz smutek. Najbardziej etycznym postępowaniem z pacjentem umierającym według personelu pielęgniarskiego jest zapewnienie mu godnych warunków umierania.

śmierć, pacjent, personel pielęgniarski, postawy wobec śmieci

Introduction. Nurses in their work more often than other professional groups have contact with human death. Nowadays, death is the source of many negative emotions that can cause increased exposure to burnout. Therefore, it is extremely important for nursing staff to have an appropriate approach to dying patients, what will allow them to provide optimal care for the patient at the end of his life.

Aim. Assessment of attitudes of nursing staff towards the death and dying of the patient.

Material and methods. The study was conducted using the diagnostic survey method with the use of the original questionnaire, which consisted of 40 questions including 26 questions of single choice, 4 questions of multiple choice and 10 questions with characteristics. The material for the study was collected in March and April 2018, the opinion of 594 registered nurses (581 women, 13 man) was examined in departments where nursing staff have frequent contact with dying patients. The analysis was carried out using the SPSS program.

Results. The most often nursing staff considers death as a natural phenomenon that every human being must meet (52.2\%). Most of the nurses approach emotionally (42.3\%) to death of patient. The most frequent emotions accompanying members of nursing teams during a patient's death are compassion (69.4\%) and sadness (67.8\%). The nursing staff considers that the most ethical treatment for a dying patient is to give him decent conditions of dying (98\%). Nurses mainly consider persistent therapy (79.6\%) as prolonging suffering. Conclusions. Nurses in contact with a dying patient most often feel compassion and sadness. The most ethical treatment of a dying patient according to nursing staff is to provide him with decent conditions for dying. 


\section{INTRODUCTION}

The literature of the subject gives many definitions of a word: attitudes, but their common element is always to define it as a kind of instruction for displaying specific behaviors in relation to a certain phenomenon [1].

Death, from the beginning of human existence, is mainly associated with the occurrence of pain, suffering and many other negative emotions. Despite the fact that it is an inseparable element of human existence, it is difficult to establish its unequivocal definition, and the specification of this phenomenon, since antiquity, has been the goal of research of medics, philosophers, clergymen and psychologists, seeking to getting to know it in every aspect. From the point of view of a man, the fact of illness and dying puts people in the face of a struggle with an extremely difficult task. Gradually, from day to day, a person stops counting on a positive solution, he or she gets used to the thought that the inevitable end of life is coming [2].

Care of a terminally ill patient usually lasts long enough to be able to make contact with him, befriend both the sick and his family. The idea of a hospice movement is understood as accompanying the dying person in the last moments of his life. It is expressed through the elimination of pain, which has an extremely negative effect on the patient in the terminal state, both in the physical and mental sphere. The death of the patient is a situation that the nursing staff has to deal with due to their profession. Despite the mastery and calmness of medical staff, such events are accompanied by a number of different emotions and feelings, which mainly include regret and lack of hope. Emotional pain belongs to factors that often cause that nurses limit contact with both the dying and his family [3].

It is worth noting that frequent contact with death has a negative impact on the nursing team not only in the workplace. Staying with the patient in an agonal state and accompanying this process creates emotions that medical staff often takes with them to the home environment, resulting in loss of self-confidence and guilt. A short-term improvement of well-being occurs when a person in contact with this phenomenon unconsciously launches defense mechanisms, mainly denial, suppression and rationalization. When the patient dies, the members of the nursing staff recall the feeling of regret, the sad memories of the past, and stimulate nervous behavior. There is also the phenomenon of irrational providing the patient with a successful prognosis and performing further examinations and tests. Due to this situation, there is a significant burden in the work of nursing staff, which may result in the development of burnout [4].

\section{AIM}

Evaluation of the attitudes of nursing staff in the face of dying and death of the patient and factors that affect individual attitudes.

\section{MATERIAL AND METHODS}

The study was conducted using the diagnostic survey method with the use of the author's questionnaire, which consisted of 40 questions, including 26 one-time choice and 4 multiple-choice questions, and 10 questions with characteristics (including for example religion). The material for the study was collected in March and April 2018. The opinion of 594 nurses (581 women and 13 men) working in hospital wards was collected, where nursing staff have frequent contact with dying patients (Anesthesiology, Neurology, Internal Medicine Department, Cardiology, Care Home, Department of Palliative Care). The respondents worked in hospitals in Rzeszów, Krosno, Jasło and Strzyżów. The analysis was carried out using the SPSS program and all relationships are important from a statistical point of view when $\mathrm{p} \leq 0.05$. Research is in line with the requirements of the Helsinki Declaration.

\section{RESULTS}

In the majority (52.2\%), nursing staff perceives death as a natural phenomenon that every human being will have to face. Death is seen as a transition „somewhere farther" $(20.0 \%)$ and release from suffering (19.0\%), the least numerous group of respondents perceives death as injustice (2.7\%). Statistical analysis has shown that younger respondents with less seniority are more likely to think that death is a natural phenomenon $(\mathrm{p}=0.03)$. Atheists understand death more as a natural phenomenon than Christians $(p=0.02)$ - Tables 1,2 .

Nurses approach the patient's death in an emotional way, but their reaction depends mainly on the situation and circumstances of death (42.3\%). Out of the surveyed group, $29.1 \%$ of respondents indicated that they are very emotional towards death, but they control their emotions, the distance is kept by $27.4 \%$ of the surveyed nursing staff. Statistical analysis has shown that respondents with a longer work experience, approach death very emotionally, but control their emotions. In turn, those working up to 5 years more often maintain distance and lack of influence on emotions $(p=0.02)$. Christians usually approach the patient's death in an emotional way, while atheists often keep the distance to this situation $(\mathrm{p}=0.009)$ - Tables 3, 4.

The most common emotions accompanying the death of patients include compassion (69.4\%), sadness (67.8\%) and helplessness (49.2\%). In the smallest percentage, members of the nursing teams felt despair $(0.3 \%)$ and anger $(1.2 \%)$.

Sadness is a feeling that occurs more often with increasing age $(\mathrm{p}=0.04$, $\mathrm{V}$ Chi-square $=9.84)$ and the seniority of the respondents $(\mathrm{p}=0.05$, Chi-square $=12.81)$. The variables were significant from the statistical point.

The factors that had the greatest impact on the attitude of nursing staff towards the act of death were the patient's age $(82.3 \%)$ and whether the death was sudden or was associated with chronic illness (76.9\%).

Among the nursing staff, the largest group is against artificial living (41.4\%), totally against euthanasia - $18.5 \%$ of respondents, and $21.5 \%$ would be reconciled 
Dawid Makowicz, Renata Dziubaszewska, Natalia Makowicz, Patrycja Barna, Monika Piękoś

Tab. 1. Perception of the concept of death depending on seniority

\begin{tabular}{|c|c|c|c|c|c|c|c|c|c|c|}
\hline & & & \multicolumn{7}{|c|}{ Seniority } & \multirow[b]{2}{*}{ In total } \\
\hline & & & $\begin{array}{c}1-5 \\
\text { years }\end{array}$ & $\begin{array}{c}5-10 \\
\text { years }\end{array}$ & $\begin{array}{l}10-15 \\
\text { years }\end{array}$ & $\begin{array}{l}15-20 \\
\text { years }\end{array}$ & $\begin{array}{l}20-25 \\
\text { years }\end{array}$ & $\begin{array}{l}25-30 \\
\text { years }\end{array}$ & \begin{tabular}{|c|} 
More than \\
30 years \\
\end{tabular} & \\
\hline \multirow{10}{*}{$\begin{array}{l}\text { What do you mean } \\
\text { by the concept of } \\
\text { death? }\end{array}$} & \multirow{2}{*}{ It's a natural phenomenon } & $\mathrm{N}$ & 113 & 34 & 28 & 23 & 43 & 30 & 39 & 310 \\
\hline & & $\%$ & $53.6 \%$ & $54.8 \%$ & $53.8 \%$ & $52.3 \%$ & $49.4 \%$ & $50.0 \%$ & $50.0 \%$ & $52.2 \%$ \\
\hline & \multirow{2}{*}{ Release from suffering } & $\mathrm{N}$ & 40 & 11 & 14 & 6 & 18 & 7 & 17 & 113 \\
\hline & & $\%$ & $19.0 \%$ & $17.7 \%$ & $26.9 \%$ & $13.6 \%$ & $20.7 \%$ & $11.7 \%$ & $21.8 \%$ & $19.0 \%$ \\
\hline & \multirow{2}{*}{ Passage „somewhere further" } & $\mathrm{N}$ & 48 & 15 & 7 & 8 & 16 & 12 & 13 & 119 \\
\hline & & $\%$ & $22.7 \%$ & $24.2 \%$ & $13.5 \%$ & $18.2 \%$ & $18.4 \%$ & $20.0 \%$ & $16.7 \%$ & $20.0 \%$ \\
\hline & \multirow{2}{*}{ Traumatic situation } & $\mathrm{N}$ & 6 & 0 & 2 & 6 & 9 & 5 & 8 & 36 \\
\hline & & $\%$ & $2.8 \%$ & $0.0 \%$ & $3.8 \%$ & $13.6 \%$ & $10.3 \%$ & $8.3 \%$ & $10.3 \%$ & $6.1 \%$ \\
\hline & \multirow{2}{*}{ Injustice } & $\mathrm{N}$ & 4 & 2 & 1 & 1 & 1 & 6 & 1 & 16 \\
\hline & & $\%$ & $1.9 \%$ & $3.2 \%$ & $1.9 \%$ & $2.3 \%$ & $1.1 \%$ & $10.0 \%$ & $1.3 \%$ & $2.7 \%$ \\
\hline \multirow{2}{*}{\multicolumn{2}{|c|}{ In total }} & $\mathrm{N}$ & 211 & 62 & 52 & 44 & 87 & 60 & 78 & 594 \\
\hline & & $\%$ & $100.0 \%$ & $100.0 \%$ & $100.0 \%$ & $100.0 \%$ & $100.0 \%$ & $100.0 \%$ & $100.0 \%$ & $100.0 \%$ \\
\hline \multicolumn{11}{|c|}{$p=0.03$, Cramer's $V=0.13$} \\
\hline
\end{tabular}

with discontinuation of therapy in the event of a patient's request not to make further persistent attempts to save his life. A larger percentage of euthanasia supporters appears in atheists $(\mathrm{p}=0.001)$. The dependence was statistically significant - Table 5 .

The vast majority of nurses $(79.6 \%)$ considers persistent therapy in the hospital as prolonging the suffering of a dying patient, only $10.9 \%$ believe that there is always a chance for a patient to recover. With the increase in age among nurses, fewer and fewer respondents believe that the use of persistent therapy in the hospital is prolonging suffering $(\mathrm{p}=0.06)$, the obtained results slightly exceeded the adopted level of statistical significance [Table 6].

The vast majority of respondents believe that the most ethical behavior towards the patient in the terminal state is to provide him with decent conditions of dying (98\%). The conviction that the most ethical behavior towards dying patients is to provide them with decent conditions of dying increases with their education ( $p=0.008, \mathrm{~V}$ Chi-square $=7.30)$, but decreases with the age of respondents $(\mathrm{p}=0.001$, Chi-square $=25.36)-$ Tables $7,8$.

The largest percentage of respondents (34.3\%) believes that one cannot get used to the death of patients. When it comes to $17.6 \%$ of respondents, they are of the opposite opinion. A significant percentage of respondents (23\%) say that if someone has become accustomed to the death of the patient, he is burned out professionally - Fig. 1 .

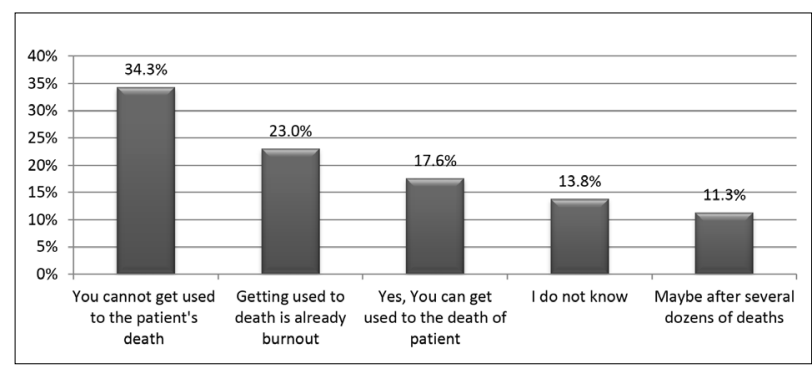

Fig 1. Opinion on the possibility of getting used to death in general terms of the whole group of respondents
Tab. 2. Perception of the concept of death depending on religion

\begin{tabular}{|c|c|c|c|c|c|c|}
\hline & & & \multicolumn{3}{|c|}{ Religion } & \multirow[b]{2}{*}{ In total } \\
\hline & & & Catholics & Atheists & $\begin{array}{c}\text { Other } \\
\text { religions }\end{array}$ & \\
\hline \multirow{10}{*}{$\begin{array}{l}\text { What do } \\
\text { you mean } \\
\text { by the } \\
\text { concept } \\
\text { of death? }\end{array}$} & \multirow{2}{*}{$\begin{array}{l}\text { It's a natural } \\
\text { phenomenon }\end{array}$} & $\mathrm{N}$ & 272 & 34 & 4 & 310 \\
\hline & & $\%$ & $50.6 \%$ & $68.0 \%$ & $66.7 \%$ & $52.2 \%$ \\
\hline & \multirow{2}{*}{$\begin{array}{c}\text { Release } \\
\text { from } \\
\text { suffering }\end{array}$} & $\mathrm{N}$ & 105 & 8 & 0 & 113 \\
\hline & & $\%$ & $19.5 \%$ & $16.0 \%$ & $0.0 \%$ & $19.0 \%$ \\
\hline & \multirow{2}{*}{$\begin{array}{c}\text { Passage } \\
\text { "somewhere } \\
\text { further" }\end{array}$} & $\mathrm{N}$ & 116 & 2 & 1 & 119 \\
\hline & & $\%$ & $21.6 \%$ & $4.0 \%$ & $16.7 \%$ & $20.0 \%$ \\
\hline & \multirow{2}{*}{$\begin{array}{l}\text { Traumatic } \\
\text { situation }\end{array}$} & $\mathrm{N}$ & 31 & 5 & 0 & 36 \\
\hline & & $\%$ & $5.8 \%$ & $10.0 \%$ & $0.0 \%$ & $6.1 \%$ \\
\hline & \multirow{2}{*}{ Injustice } & $\mathrm{N}$ & 14 & 1 & 1 & 16 \\
\hline & & $\%$ & $2.6 \%$ & $2.0 \%$ & $16.7 \%$ & $2.7 \%$ \\
\hline \multirow{2}{*}{\multicolumn{2}{|c|}{ In total }} & $\mathrm{N}$ & 538 & 50 & 6 & 594 \\
\hline & & $\%$ & $100.0 \%$ & $100.0 \%$ & $100.0 \%$ & $100.0 \%$ \\
\hline \multicolumn{7}{|c|}{$\mathrm{p}=0.02$, Cramer's V $=0.12$} \\
\hline
\end{tabular}

\section{DISCUSSION}

In order to be able to speak more broadly about the issue of attitudes towards death, it is important to ask what death really is for people working in health care. In the author's study, the highest percentage of nurses perceives the phenomenon of death as something natural with which everyone will have to face one day (52.2\%). You can use the maxim here: „Death is not the end, but the shade, the modality of life, and life - the shade of death" by Jean Baudrillard. In the Krajewska-Kułak study it turned out that members of nursing teams in the case of contact with dying people usually accept death and treat it as a natural phenomenon (40.4\%). Zawiślak in her work showed that $61 \%$ of nurses thinking about their own death are characterized by understanding and acceptance of this inevitable fact. Miczka-Pajestka, in her works on the perception of 


\section{The attitude of nursing staff towards the death and dying of the patient}

Tab. 3. Emotional approach depending on seniority

\begin{tabular}{|c|c|c|c|c|c|c|c|c|c|c|}
\hline & \multicolumn{7}{|c|}{ Seniority } & \multirow[b]{2}{*}{ In total } \\
\hline & & & $\begin{array}{c}1-5 \\
\text { years }\end{array}$ & $\begin{array}{c}5-10 \\
\text { years }\end{array}$ & $\begin{array}{l}10-15 \\
\text { years }\end{array}$ & $\begin{array}{l}15-20 \\
\text { years }\end{array}$ & $\begin{array}{l}20-25 \\
\text { years }\end{array}$ & $\begin{array}{l}25-30 \\
\text { years }\end{array}$ & $\begin{array}{c}\text { More than } \\
30 \text { years }\end{array}$ & \\
\hline \multirow{8}{*}{$\begin{array}{l}\text { What is your attitude } \\
\text { towards the death of } \\
\text { the patient? }\end{array}$} & \multirow{2}{*}{$\begin{array}{l}\text { I approach it emotionally, but I } \\
\text { control my emotions }\end{array}$} & $\mathrm{N}$ & 53 & 13 & 12 & 10 & 34 & 22 & 29 & 173 \\
\hline & & $\%$ & $25.1 \%$ & $21.0 \%$ & $23.1 \%$ & $22.7 \%$ & $39.1 \%$ & $36.7 \%$ & $37.2 \%$ & $29.1 \%$ \\
\hline & \multirow{2}{*}{$\begin{array}{l}\text { I approach it emotionally, but my } \\
\text { reaction depends on the situation } \\
\text { and circumstances of death }\end{array}$} & $\mathrm{N}$ & 81 & 33 & 30 & 21 & 29 & 20 & 37 & 251 \\
\hline & & $\%$ & $38.4 \%$ & $53.2 \%$ & $57.7 \%$ & $47.7 \%$ & $33.3 \%$ & $33.3 \%$ & $47.4 \%$ & $42.3 \%$ \\
\hline & \multirow{2}{*}{$\begin{array}{l}\text { I react very emotionally, I find it } \\
\text { difficult to control myself }\end{array}$} & $\mathrm{N}$ & 3 & 0 & 1 & 1 & 1 & 1 & 0 & 7 \\
\hline & & $\%$ & $1.4 \%$ & $0.0 \%$ & $1.9 \%$ & $2.3 \%$ & $1.1 \%$ & $1.7 \%$ & $0.0 \%$ & $1.2 \%$ \\
\hline & \multirow{2}{*}{$\begin{array}{l}\text { I keep distance, it does not affect } \\
\text { my emotions too much }\end{array}$} & N & 74 & 16 & 9 & 12 & 23 & 17 & 12 & 163 \\
\hline & & $\%$ & $35.1 \%$ & $25.8 \%$ & $17.3 \%$ & $27.3 \%$ & $26.4 \%$ & $28.3 \%$ & $15.4 \%$ & $27.4 \%$ \\
\hline \multirow{2}{*}{\multicolumn{2}{|c|}{ In total }} & $\mathrm{N}$ & 211 & 62 & 52 & 44 & 87 & 60 & 78 & 594 \\
\hline & & $\%$ & $100.0 \%$ & $100.0 \%$ & $100.0 \%$ & $100.0 \%$ & $100.0 \%$ & $100.0 \%$ & $100.0 \%$ & $100.0 \%$ \\
\hline \multicolumn{11}{|c|}{$\mathrm{p}=0.02$, Cramer's $\mathrm{V}=0.13, \mathrm{Chi}^{2}=31.98(\mathrm{df}=18)$} \\
\hline
\end{tabular}

Tab. 4. Emotional approach depending on religion

\begin{tabular}{|c|c|c|c|c|c|c|}
\hline & \multicolumn{3}{|c|}{ Religion } & \multirow{2}{*}{$\underset{\text { total }}{\text { In }}$} \\
\hline & & & Catholics & Atheists & \begin{tabular}{|c|} 
Other \\
religions \\
\end{tabular} & \\
\hline \multirow{8}{*}{$\begin{array}{l}\text { What } \\
\text { is your } \\
\text { attitude } \\
\text { towards } \\
\text { the death } \\
\text { of the } \\
\text { patient? }\end{array}$} & \multirow{2}{*}{$\begin{array}{l}\text { I approach it } \\
\text { emotionally, } \\
\text { but I control } \\
\text { my emotions }\end{array}$} & N & 166 & 7 & 0 & 173 \\
\hline & & $\%$ & $30.9 \%$ & $14.0 \%$ & $0.0 \%$ & $29.1 \%$ \\
\hline & \multirow{2}{*}{$\begin{array}{l}\text { I approach it } \\
\text { emotionally, } \\
\text { but my reaction } \\
\text { depends on the } \\
\text { situation and } \\
\text { circumstances } \\
\text { of death }\end{array}$} & $\mathrm{N}$ & 229 & 19 & 3 & 251 \\
\hline & & $\%$ & $42.6 \%$ & $38.0 \%$ & $50.0 \%$ & $42.3 \%$ \\
\hline & \multirow{2}{*}{$\begin{array}{l}\text { I react very } \\
\text { emotionally, } \\
\text { I find it difficult } \\
\text { to control } \\
\text { myself }\end{array}$} & $\mathrm{N}$ & 7 & 0 & 0 & 7 \\
\hline & & $\%$ & $1.3 \%$ & $0.0 \%$ & $0.0 \%$ & $1.2 \%$ \\
\hline & \multirow{2}{*}{$\begin{array}{l}\text { I keep distance, } \\
\text { it does not affect } \\
\text { my emotions } \\
\text { too much }\end{array}$} & N & 136 & 24 & 3 & 163 \\
\hline & & $\%$ & $25.3 \%$ & $48.0 \%$ & $50.0 \%$ & $27.4 \%$ \\
\hline & \multirow{2}{*}{ In total } & N & 538 & 50 & 6 & 594 \\
\hline & & $\%$ & $100.0 \%$ & $100.0 \%$ & $100.0 \%$ & $100.0 \%$ \\
\hline \multicolumn{7}{|c|}{$\mathrm{p}=0.009$, Cramer's V $=0.12$} \\
\hline
\end{tabular}

Tab. 5. Attitudes of nursing staff depending on religion

\begin{tabular}{|c|c|c|c|c|c|c|}
\hline & \multicolumn{3}{|c|}{ Religion } & \multirow{2}{*}{$\begin{array}{l}\text { In } \\
\text { total }\end{array}$} \\
\hline & & & Catholics & Atheists & \begin{tabular}{|c|}
$\begin{array}{c}\text { Other } \\
\text { religions }\end{array}$ \\
\end{tabular} & \\
\hline \multirow{8}{*}{$\begin{array}{l}\text { What is } \\
\text { your } \\
\text { opinion } \\
\text { about } \\
\text { euthanasia? }\end{array}$} & \multirow{2}{*}{$\begin{array}{l}\text { I am } \\
\text { against the } \\
\text { euthanasiav }\end{array}$} & $\mathrm{N}$ & 108 & 1 & 1 & 110 \\
\hline & & $\%$ & $20.1 \%$ & $2.0 \%$ & $16.7 \%$ & $18.5 \%$ \\
\hline & \multirow{2}{*}{$\begin{array}{l}\text { If I know } \\
\text { that further } \\
\text { treatment } \\
\text { does not } \\
\text { make sense, } \\
\text { I am against } \\
\text { artificial living }\end{array}$} & $\mathrm{N}$ & 216 & 27 & 3 & 246 \\
\hline & & $\%$ & $40.1 \%$ & $54.0 \%$ & $50.0 \%$ & $41.4 \%$ \\
\hline & \multirow{2}{*}{$\begin{array}{c}\text { I am for if } \\
\text { the patient } \\
\text { wants it }\end{array}$} & $\mathrm{N}$ & 107 & 19 & 2 & 128 \\
\hline & & $\%$ & $19.9 \%$ & $38.0 \%$ & $33.3 \%$ & $21.5 \%$ \\
\hline & \multirow{2}{*}{$\begin{array}{l}\text { I do not have } \\
\text { any opinion }\end{array}$} & $\mathrm{N}$ & 107 & 3 & 0 & 110 \\
\hline & & $\%$ & $19.9 \%$ & $6.0 \%$ & $0.0 \%$ & $18.5 \%$ \\
\hline \multirow{2}{*}{\multicolumn{2}{|c|}{ In total }} & $\mathrm{N}$ & 538 & 50 & 6 & 594 \\
\hline & & $\%$ & $100.0 \%$ & $100.0 \%$ & $100.0 \%$ & $100.0 \%$ \\
\hline \multicolumn{7}{|c|}{$\mathrm{p}=0.001$, Cramer's V $=0.14$} \\
\hline
\end{tabular}

Tab. 6. Opinion regarding the use of persistent therapy depending on age

\begin{tabular}{|c|c|c|c|c|c|c|c|c|}
\hline & \multicolumn{5}{|c|}{ Age } & \multirow[b]{2}{*}{ In total } \\
\hline & & & $\begin{array}{l}22-29 \\
\text { years }\end{array}$ & $\begin{array}{l}30-39 \\
\text { years }\end{array}$ & $\begin{array}{l}40-49 \\
\text { years }\end{array}$ & $\begin{array}{l}50-59 \\
\text { years }\end{array}$ & $\begin{array}{c}60 \text { years } \\
\text { and more }\end{array}$ & \\
\hline \multirow{6}{*}{$\begin{array}{l}\text { The use of persistent therapy } \\
\text { in a hospital is, according } \\
\text { to you: }\end{array}$} & \multirow{2}{*}{ Prolonging suffering } & $\mathrm{N}$ & 170 & 92 & 144 & 62 & 5 & 473 \\
\hline & & $\%$ & $82.5 \%$ & $84.4 \%$ & $76.6 \%$ & $76.5 \%$ & $50.0 \%$ & $79.6 \%$ \\
\hline & \multirow{2}{*}{$\begin{array}{l}\text { Prolonging life, there is always } \\
\text { a chance of recovery }\end{array}$} & $\mathrm{N}$ & 16 & 11 & 23 & 11 & 4 & 65 \\
\hline & & $\%$ & $7.8 \%$ & $10.1 \%$ & $12.2 \%$ & $13.6 \%$ & $40.0 \%$ & $10.9 \%$ \\
\hline & \multirow{2}{*}{ I do not have opinion } & $\mathrm{N}$ & 20 & 6 & 21 & 8 & 1 & 56 \\
\hline & & $\%$ & $9.7 \%$ & $5.5 \%$ & $11.2 \%$ & $9.9 \%$ & $10.0 \%$ & $9.4 \%$ \\
\hline \multirow{2}{*}{\multicolumn{2}{|c|}{ In total }} & $\mathrm{N}$ & 206 & 109 & 188 & 81 & 10 & 594 \\
\hline & & $\%$ & $100.0 \%$ & $100.0 \%$ & $100.0 \%$ & $100.0 \%$ & $100.0 \%$ & $100.0 \%$ \\
\hline \multicolumn{9}{|c|}{$p=0.06$} \\
\hline
\end{tabular}


Dawid Makowicz, Renata Dziubaszewska, Natalia Makowicz, Patrycja Barna, Monika Piękoś

Tab. 7. Dealing with the dying patient considered as the most ethical depending on the school completed

\begin{tabular}{|c|c|c|c|c|c|c|c|}
\hline & & & \multicolumn{4}{|c|}{ Type of finished school } & \multirow[b]{2}{*}{ In total } \\
\hline & & & $\begin{array}{c}\text { Medical } \\
\text { highschool }\end{array}$ & $\begin{array}{l}\text { Post- } \\
\text { secondary } \\
\text { school }\end{array}$ & $\begin{array}{l}\text { Bachelor } \\
\text { Studies }\end{array}$ & $\begin{array}{l}\text { Master's } \\
\text { Studies }\end{array}$ & \\
\hline \multirow{6}{*}{$\begin{array}{l}\text { What do you think is the most ethical } \\
\text { behaviour with a dying patient in the } \\
\text { terminal state? }\end{array}$} & \multirow{2}{*}{$\begin{array}{l}\text { Provide him with dignified } \\
\text { conditions for dying }\end{array}$} & $\mathrm{N}$ & 46 & 37 & 267 & 232 & 582 \\
\hline & & $\%$ & $92.0 \%$ & $97.4 \%$ & $98.2 \%$ & $99.1 \%$ & $98.0 \%$ \\
\hline & \multirow{2}{*}{$\begin{array}{c}\text { Use all means to sustain } \\
\text { and save life }\end{array}$} & $\mathrm{N}$ & 4 & 1 & 3 & 1 & 9 \\
\hline & & $\%$ & $8.0 \%$ & $2.6 \%$ & $1.1 \%$ & $0.4 \%$ & $1.5 \%$ \\
\hline & \multirow{2}{*}{ I do not have opinion } & $\mathrm{N}$ & 0 & 0 & 2 & 1 & 3 \\
\hline & & $\%$ & $0.0 \%$ & $0.0 \%$ & $0.7 \%$ & $0.4 \%$ & $0.5 \%$ \\
\hline \multirow{2}{*}{\multicolumn{2}{|c|}{ In total }} & $\mathrm{N}$ & 50 & 38 & 272 & 234 & 594 \\
\hline & & $\%$ & $100.0 \%$ & $100.0 \%$ & $100.0 \%$ & $100.0 \%$ & $100.0 \%$ \\
\hline \multicolumn{8}{|c|}{$\mathrm{p}=0.008$, Cramer's V $=0.12, \mathrm{Chi}^{2}=7.30(\mathrm{df}=6)$} \\
\hline
\end{tabular}

Tab. 8. The most ethical treatment of a dying patient in the opinion of respondents depending on their age

\begin{tabular}{|c|c|c|c|c|c|c|c|c|}
\hline & & & \multicolumn{5}{|c|}{ Age } & \multirow[b]{2}{*}{ In total } \\
\hline & & & $22-29$ years & $30-39$ years & $40-49$ years & $50-59$ years & $\begin{array}{c}60 \text { years } \\
\text { and more }\end{array}$ & \\
\hline \multirow{6}{*}{$\begin{array}{l}\text { What do you think is the } \\
\text { most ethical behaviour } \\
\text { with a dying patient } \\
\text { in the terminal state? }\end{array}$} & \multirow{2}{*}{$\begin{array}{l}\text { Provide him with dignified } \\
\text { conditions for dying }\end{array}$} & $\mathrm{N}$ & 201 & 108 & 185 & 80 & 8 & 582 \\
\hline & & $\%$ & $97.6 \%$ & $99.1 \%$ & $98.4 \%$ & $98.8 \%$ & $80.0 \%$ & $98.0 \%$ \\
\hline & \multirow{2}{*}{$\begin{array}{l}\text { Use all means to sustain and } \\
\text { save life }\end{array}$} & $\mathrm{N}$ & 3 & 1 & 2 & 1 & 2 & 9 \\
\hline & & $\%$ & $1.5 \%$ & $0.9 \%$ & $1.1 \%$ & $1.2 \%$ & $20.0 \%$ & $1.5 \%$ \\
\hline & \multirow{2}{*}{ I do not have opinion } & $\mathrm{N}$ & 2 & 0 & 1 & 0 & 0 & 3 \\
\hline & & $\%$ & $1.0 \%$ & $0.0 \%$ & $0.5 \%$ & $0.0 \%$ & $0.0 \%$ & $0.5 \%$ \\
\hline \multirow{2}{*}{\multicolumn{2}{|c|}{ In total }} & $\mathrm{N}$ & 206 & 109 & 188 & 81 & 10 & 594 \\
\hline & & $\%$ & $100.0 \%$ & $100.0 \%$ & $100.0 \%$ & $100.0 \%$ & $100.0 \%$ & $100.0 \%$ \\
\hline \multicolumn{9}{|c|}{$\mathrm{p}=0.001$, Cramer's V $=0.15, \mathrm{Chi}^{2}=25.36(\mathrm{df}=8)$} \\
\hline
\end{tabular}

death, also saw that this is a natural phenomenon which connects all people, both rich and poor, because no one can escape from death, in the end everyone must face it $[5,6,7]$.

Death is a phenomenon that evokes certain behaviors. Most of the respondents emotionally approached patients' deaths. The main emotions appearing in the nursing staff while caring for a person at the end of his/her life were compassion $(69.4 \%)$ and sadness $(67.8 \%)$. Also, in the study conducted by Sleziona, the majority of people who emotionally approached the death of the patient were able to control their emotions (50.8\%). In addition, she showed that the most common emotions associated with the death of the patient were sadness (70\%) and compassion (67\%). In the Niedojad's study, it was found that the most popular reaction that accompanied the nursing staff in the situation of death of the patient was sadness (82\%). Sadness was the most common symptom triggered by the death of patients as well in the Januszewska’s study (71\%). Głowacka, analyzing the death of patients as a burden factor in the professional work of nursing staff, showed that sadness $(82.7 \%)$ and compassion (74\%) were most often felt. Ek's research on nursing students showed that the most common emotions at the death of patients were sadness, vulnerability and helplessness associated with little experience in the profession [8-12].
Own research has shown that the intensity of emotions arises depending on the situation and circumstances of death. The conducted analysis showed that greater emotions occur in nursing staff in the case of the death of younger patients $(82.3 \%)$ and when death occurs suddenly (76.9\%). Confirmation of the results obtained is found in Sleziona, where $51 \%$ of respondents felt the greatest emotions when the child died. In the Niedojad's study, the statistical analyzes showed that the main factors that influence the behavior of nursing staff in the face of dying and death are the patient's age (98\%) and sudden, unexpected death (97\%). In addition, Zawiślak shows that the most pejorative feelings arise as a result of the child's death. The assumed hypothesis is also confirmed by foreign surveys. Fitch, studying the professional group of nurses, discovered that they are more emotionally concerned about the death of young people, because they think that "they did not have time to realize their potential”, the greatest emotions were caused by the death of a child. Wilson, when interviewing the entire therapeutic team, observed that the death of patients of their age and younger than them was particularly difficult for them $[7-9,13,14]$.

The author's research showed that the theme of euthanasia still remains a contentious issue. In many cases it is considered acceptable for respondents to abandon persistent therapy in situations where the prognosis does not give the patient a chance of survival $(41.4 \%)$ or when the 
patient himself asks to abandon making futile attempts to save his life (21.5\%). It is also worth noting that persistent therapy in the eyes of nurses is perceived mainly as prolonging patients' suffering (79.6\%). The fact that expressing approval for the use of euthanasia is a controversial issue can be observed in the analyzes of Mickiewicz, where euthanasia was accepted by $42 \%$ of respondents, while $40 \%$ made disapproval. In the world's research, there is a very interesting relationship regarding the acceptance of euthanasia in different countries, in Germany it was $82 \%$, in the United States $80 \%$, in Canada $76 \%, 61 \%$ in Sweden, while $42 \%$ in Poland. Mickiewicz also showed that $48.9 \%$ of nurses agree to disconnect artificial life support equipment if the patient does not prognosticate the improvement of health $[15,16]$.

The conducted research has shown that nurses consider the most ethical behavior towards a person in the terminal state to provide him/her with decent conditions of dying (98\%). In her analyzes, Sleziona showed that $70.8 \%$ of nurses consider as the most important to show a respectful attitude and empathy when performing nursing care for a terminally ill patient. In a study conducted by Kurleto-Kalitowska, nurses considered that in the case of terminally ill patients they should be provided first of all nursing care (42.5\%), discontinue persistent therapy (40\%) and use only analgesia (37.5\%). In addition, $80 \%$ of the respondents were of the opinion that if they were to make decisions on how to deal with terminally ill patients, they would decide not to continue their persistent therapy. Rui-Shuang, conducting research among Chinese medical staff, showed that according to nurses, the most important thing in dealing with the patient in the terminal state is taking nursing care and relieving pain $[8,17,18]$.

Surveyed members of nursing teams mostly believe that one cannot get used to the patient's death (34.3\%), and some of them consider being accustomed to death as synonymous with professional burnout (23\%). An even higher result was achieved in the research work of Januszewska, where $68 \%$ of health care workers believe that one cannot get used to the death of patients. In her studies, Sleziona reached a lower level of negative answers (33.4\%), but in the study she used the word „immunize” instead of "getting used to". In her study, also the percentage of people claiming that getting used to death is already burnout (14.2\%) is also noticeable. However, in Marcysiak's study, daily contact with patient's death was the third most common factor causing stress in nursing work $(62 \%)[8,10,19]$.

\section{CONCLUSIONS}

1. Death is perceived by nurses as a natural phenomenon, which everyone will have to face someday.

2. For nursing staff death is a phenomenon that causes the appearance of many negative emotions, among which sadness and compassion prevail. Along with the increase in seniority and the age of nurses, sadness is more common.

3. The main factors determining the intensity of emotions in the situation of patients' death is the patient's age and the type of death. More emotions result in the death of younger people and when death suddenly occurs.

4. The approval of euthanasia remains a contentious issue, however, an increasing number of people working in medical professions allow for the cessation of persistent therapy. The atheists exhibit more permission for euthanasia.

5. The most ethical behavior towards a dying patient in the opinion of the nursing team is to provide him with decent death conditions. This belief grows with level of education.

6. No one can get used to the death of a patient, and symptoms of such behavior are perceived as symptoms of burnout.

\section{Postawy personelu pielęgniarskiego wobec śmierci i umierania pacjenta}

\section{WPROWADZENIE}

Literatura przedmiotu podaje wiele definicji postaw, jednak wspólnym ich elementem jest zawsze określenie jej jako swego rodzaju dyspozycji do przejawiania określonych zachowań w stosunku do pewnego zjawiska [1].

Śmierć już od początków istnienia ludzkości kojarzy się głównie z występowaniem bólu, cierpienia oraz wieloma innymi negatywnymi emocjami. Pomimo faktu, iż jest nieodłącznym elementem ludzkiej egzystencji to trudno jest ustalić jej jednoznaczną definicję, a sprecyzowanie tego zjawiska już od starożytności stanowi cel badań medyków, filozofów, duchownych oraz psychologów, dążących do poznania jej w każdym aspekcie. Z punktu widzenia człowieka, fakt choroby i umierania stawia ludzi w obliczu zmagania się z niezwykle trudnym zadaniem. Stopniowo z dnia na dzień osoba chora przestaje liczyć na pozytywne rozwiązanie, przyzwyczaja się do myśli, iż nadchodzi nieuchronny kres życia [2].

Opieka nad pacjentem terminalnym $z$ reguły trwa wystarczająco długo, aby móc nawiązać z nim kontakt, zaprzyjaźnić się zarówno z chorym, jak i jego rodziną. Ideę ruchu hospicyjnego rozumie się jako towarzyszenie umierającemu w ostatnich momentach jego życia. Wyraża się ona poprzez zniesienie bólu, który niezwykle negatywnie wpływa na chorego w stanie terminalnym zarówno w sferze fizycznej jak i psychicznej. Śmierć chorego jest sytuacją, z którą z racji wykonywanego zawodu musi się zmierzyć personel pielęgniarski. Pomimo opanowania i spokoju personelu medycznego, takim zdarzeniom 
towarzyszy szereg różnych emocji i uczuć, do których należy zaliczyć głównie żal i brak nadziei. Ból emocjonalny należy do czynników, które niejednokrotnie powodują znaczne ograniczanie przez pielęgniarki i pielęgniarzy kontaktu zarówno z umierającym jak i jego najbliższymi [3].

Warto podkreślić, iż częste obcowanie ze śmiercią ma negatywny wpływ na zespół pielęgniarski nie tylko $\mathrm{w}$ miejscu pracy. Przebywanie z pacjentem w stanie agonalnym oraz towarzyszenie temu procesowi powoduje powstawanie emocji, które personel medyczny często zabiera ze sobą do środowiska domowego, w skutek czego dochodzi do utraty pewności siebie oraz poczucia winy. Do krótkotrwałej poprawy samopoczucia dochodzi, gdy osoba stykająca się z tym zjawiskiem w sposób nieświadomy uruchamia mechanizmy obronne, głównie zaprzeczenie, tłumienie, wyparcie oraz racjonalizację. W sytuacji umierania człowieka hospitalizowanego członkowie personelu pielęgniarskiego przywołują w pamięci poczucie żalu, smutne wspomnienia z przeszłości, jak również dochodzi do stymulowania nerwowych zachowań. Powstaje również zjawisko irracjonalnego zapewniania chorego o pomyślnym rokowaniu i zasadności wykonywania kolejnych badań. W związku z taką sytuacją dochodzi do znacznego obciążenia w pracy zawodowej personelu pielęgniarskiego, co może skutkować rozwijaniem się wypalenia zawodowego [4].

\section{CEL}

Ocena występujących postaw personelu pielęgniarskiego wobec umierania i śmierci pacjenta oraz czynników, które mają wpływ na poszczególne postawy.

\section{MATERIAŁ I METODY}

Badanie zostało przeprowadzone za pomocą metody sondażu diagnostycznego z wykorzystaniem autorskiego kwestionariusza ankiety składającego się łącznie z 40 pytań, w tym 26 zamkniętych jednokrotnego i 4 wielokrotnego wyboru oraz 10 pytań metryczki, które dotyczyły m. in. wyznania. Materiał do badania został zebrany w marcu i kwietniu 2018 r., zbadano opinię 581 pielęgniarek i 13 pielęgniarzy pracujących na oddziałach szpitalnych, gdzie personel pielęgniarski ma częsty kontakt z pacjentami umierającymi (OIT, Neurologia, Interna, Kardiologia, Zakład Opiekuńczo-Lecznicy, Odział Opieki Paliatywnej). Ankietowane osoby pracowały w szpitalach w Rzeszowie, Krośnie, Jaśle i Strzyżowie. Analiza została przeprowadzona za pomocą programu SPSS a wszelkie związki są istotne statystycznie, gdy $\mathrm{p} \leq 0,05$. Badania są zgodne z wymogami Deklaracji Helsińskiej.

\section{WYNIKI}

W największym stopniu (52,2\%) personel pielęgniarski postrzega śmierć jako naturalne zjawisko, z którym będzie musiał zmierzyć się każdy człowiek. Niemal w równym stopniu śmierć jest widziana jako przejście „gdzieś dalej” $(20,0 \%)$ oraz uwolnienie od cierpienia $(19,0 \%)$, najmniej osób odbiera śmierć jako niesprawiedliwość $(2,7 \%)$. Analiza statystyczna wykazała, iż badani z krótszym stażem pracy częściej są zdania, że śmierć jest naturalnym zjawiskiem ( $\mathrm{p}=0,03)$. Ateiści w większym stopniu niż chrześcijanie pojęcie śmierci rozumieją jako naturalne zjawisko $(\mathrm{p}=0,02)$ - Tabela 1,2 .

Pielęgniarki i pielęgniarze podchodzą do śmierci pacjenta w sposób emocjonalny, jednak ich reakcja zależy głównie od sytuacji i okoliczności zgonu (42,3\%). Z badanej grupy $29,1 \%$ respondentów wskazało, że do śmierci podchodzi bardzo emocjonalnie, jednak kontroluje swoje emocje, dystans zachowuje 27,4\% badanych członków personelu pielęgniarskiego. Analiza statystyczna wykazała, iż badani z dłuższym stażem pracy do śmierci podchodzą bardzo emocjonalnie, jednak kontrolują swoje emocje. Z kolei pracujący do 5 lat częściej zachowują dystans i brak wpływu na emocje $(\mathrm{p}=0,02)$. Chrześcijanie przeważnie podchodzą do śmierci pacjenta w sposób emocjonalny, natomiast ateiści częściej od chrześcijan zachowują dystans do śmierci pacjenta $(\mathrm{p}=0,009)$ - Tabela 3, 4 .

Tab. 1. Postrzeganie pojęcia śmierci w zależności od stażu pracy

\begin{tabular}{|c|c|c|c|c|c|c|c|c|c|c|}
\hline & & & \multicolumn{7}{|c|}{ Staż pracy } & \multirow[b]{2}{*}{ Ogółem } \\
\hline & & & $1-5$ lat & $5-10$ lat & 10-15 lat & 15-20 lat & 20-25 lat & 25-30 lat & $\begin{array}{l}\text { Powyżej } \\
30 \text { lat }\end{array}$ & \\
\hline \multirow{10}{*}{$\begin{array}{l}\text { Co rozumie } \\
\text { Pani/Pan przez } \\
\text { pojęcie śmierci? }\end{array}$} & \multirow{2}{*}{ Jest to naturalne zjawisko } & $\mathrm{N}$ & 113 & 34 & 28 & 23 & 43 & 30 & 39 & 310 \\
\hline & & $\%$ & $53,6 \%$ & $54,8 \%$ & $53,8 \%$ & $52,3 \%$ & $49,4 \%$ & $50,0 \%$ & $50,0 \%$ & $52,2 \%$ \\
\hline & \multirow{2}{*}{ Uwolnienie od cierpienia } & $\mathrm{N}$ & 40 & 11 & 14 & 6 & 18 & 7 & 17 & 113 \\
\hline & & $\%$ & $19,0 \%$ & $17,7 \%$ & $26,9 \%$ & $13,6 \%$ & $20,7 \%$ & $11,7 \%$ & $21,8 \%$ & $19,0 \%$ \\
\hline & \multirow{2}{*}{ Przejście „gdzieś dalej” } & $\mathrm{N}$ & 48 & 15 & 7 & 8 & 16 & 12 & 13 & 119 \\
\hline & & $\%$ & $22,7 \%$ & $24,2 \%$ & $13,5 \%$ & $18,2 \%$ & $18,4 \%$ & $20,0 \%$ & $16,7 \%$ & $20,0 \%$ \\
\hline & \multirow{2}{*}{ Zdarzenie traumatyczne } & $\mathrm{N}$ & 6 & 0 & 2 & 6 & 9 & 5 & 8 & 36 \\
\hline & & $\%$ & $2,8 \%$ & $0,0 \%$ & $3,8 \%$ & $13,6 \%$ & $10,3 \%$ & $8,3 \%$ & $10,3 \%$ & $6,1 \%$ \\
\hline & \multirow{2}{*}{ Niesprawiedliwość } & $\mathrm{N}$ & 4 & 2 & 1 & 1 & 1 & 6 & 1 & 16 \\
\hline & & $\%$ & $1,9 \%$ & $3,2 \%$ & $1,9 \%$ & $2,3 \%$ & $1,1 \%$ & $10,0 \%$ & $1,3 \%$ & $2,7 \%$ \\
\hline & \multirow{2}{*}{ Ogółem } & $\mathrm{N}$ & 211 & 62 & 52 & 44 & 87 & 60 & 78 & 594 \\
\hline & & $\%$ & $100,0 \%$ & $100,0 \%$ & $100,0 \%$ & $100,0 \%$ & $100,0 \%$ & $100,0 \%$ & $100,0 \%$ & $100,0 \%$ \\
\hline \multicolumn{11}{|c|}{$p=0,03$, V Kramera $=0,13$} \\
\hline
\end{tabular}


Do najczęstszych emocji towarzyszących śmieci pacjentów zalicza się współczucie $(69,4 \%)$, smutek $(67,8 \%)$ oraz bezradność $(49,2 \%)$. W najmniejszym stopniu członkowie zespołów pielęgniarskich odczuwali rozpacz $(0,3 \%)$ i gniew $(1,2 \%)$.

Smutek jest uczuciem, które częściej pojawia się wraz ze wzrostem wieku ( $\mathrm{p}=0,04, \mathrm{~V}$ Chi-kwadrat $=9,84)$ oraz stażu pracy respondentów ( $\mathrm{p}=0,05$, Chi-kwadrat=12,81). Związki zmiennych były istotne statystycznie.

Czynnikami, które w największym stopniu wpływały na postawę personelu pielęgniarskiego wobec śmierci był wiek pacjenta $(82,3 \%)$ oraz fakt czy zgon był nagły czy też wiązał się z występowaniem przewlekłej choroby $(76,9 \%)$.

Spośród członków personelu pielęgniarskiego największa grupa opowiada się przeciwko sztucznemu utrzymywaniu życia (41,4\%), całkowicie przeciwne eutanazji jest 18,5\% badanych, natomiast $21,5 \%$ pogodziłoby się z przerwaniem terapii w sytuacji prośby pacjenta, a nie dokonywanie dalszych uporczywych prób ratowania jego życia. Większy odsetek zwolenników eutanazji pojawia się u ateistów $(\mathrm{p}=0,001)$. Zależność była istotna statystycznie - Tabela 5 .

\section{Tab. 2. Postrzeganie pojęcia śmierci w zależności od wyznania}

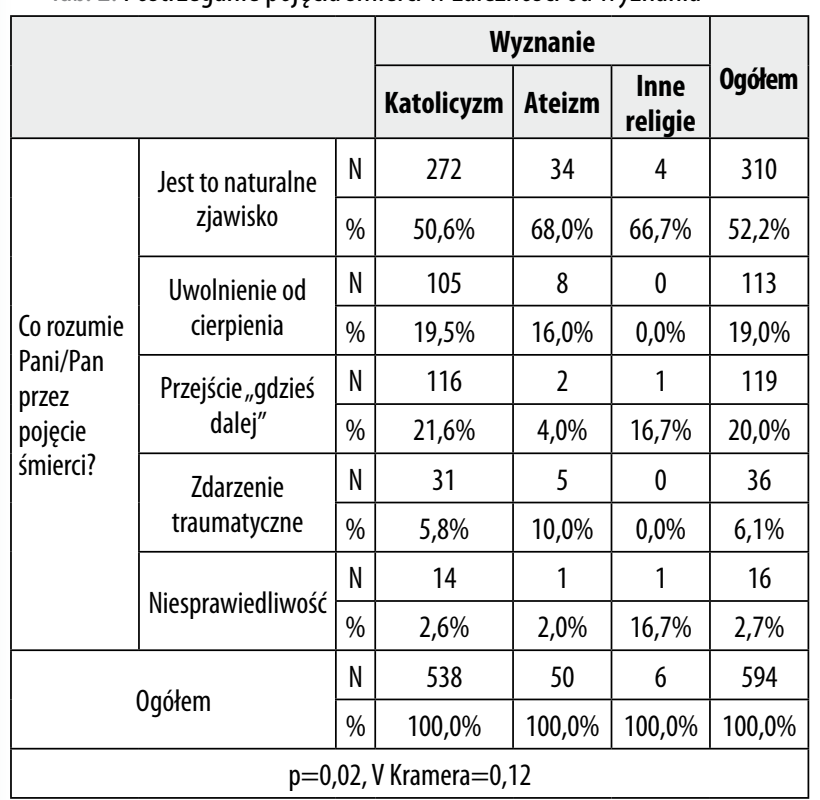

Zdecydowana większość badanych pielęgniarek i pielęgniarzy $(79,6 \%)$ uporczywą terapię w szpitalu uważa jako przedłużanie cierpienia, tylko 10,9\% jest zdania, iż zawsze istnieje szansa na powrót chorego do zdrowia. Wraz ze wzrostem wieku pośród pielęgniarek i pielęgniarzy coraz mniej z nich uważa, że stosowanie uporczywej terapii w szpitalu jest przedłużaniem cierpienia $(\mathrm{p}=0,06)$, otrzymane wyniki nieznacznie przekroczyły przyjęty poziom istotności statystycznej - Tabela 6.

Zdecydowana większość ankietowanych pielęgniarek i pielęgniarzy jako najbardziej etyczne postępowanie wobec pacjenta $\mathrm{w}$ terminalnym stanie uważa zapewnienie mu godnych warunków umierania (98\%). Przekonanie o tym, iż najbardziej etycznym postępowaniem wobec pacjentów umierających jest zapewnienie im godnych warunków umierania rośnie wraz z posiadanym wykształceniem ( $\mathrm{p}=0,008$, V Chi-kwadrat $=7,30$ ), jednak zmniejsza się wraz $\mathrm{z}$ wiekiem respondentów ( $\mathrm{p}=0,001$, Chi-kwadrat=25,36) - Tabela 7, 8 .

Największy odsetek respondentów (34,3\%) jest zdania, iż do śmierci pacjentów nie można się przyzwyczaić, przeciwnego zdania jest $17,6 \%$ badanych. Znaczący odsetek ankietowanych (23\%) uważa, iż przyzwyczajenie do śmierci pacjenta świadczy o rozwijającym się wypaleniu zawodowym - Ryc. 1.

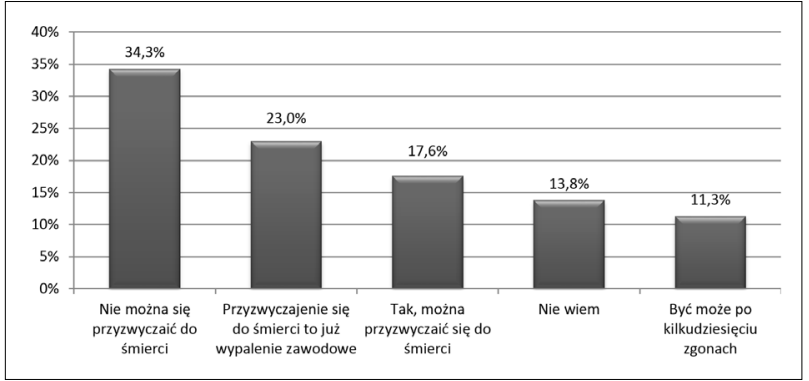

Ryc 1. Opinia dotycząca możliwości przyzwyczajenia się do śmierci w ogólnym ujęciu całej grupy badanej

Tab. 3. Nastawienie emocjonalne w zależności od stażu pracy

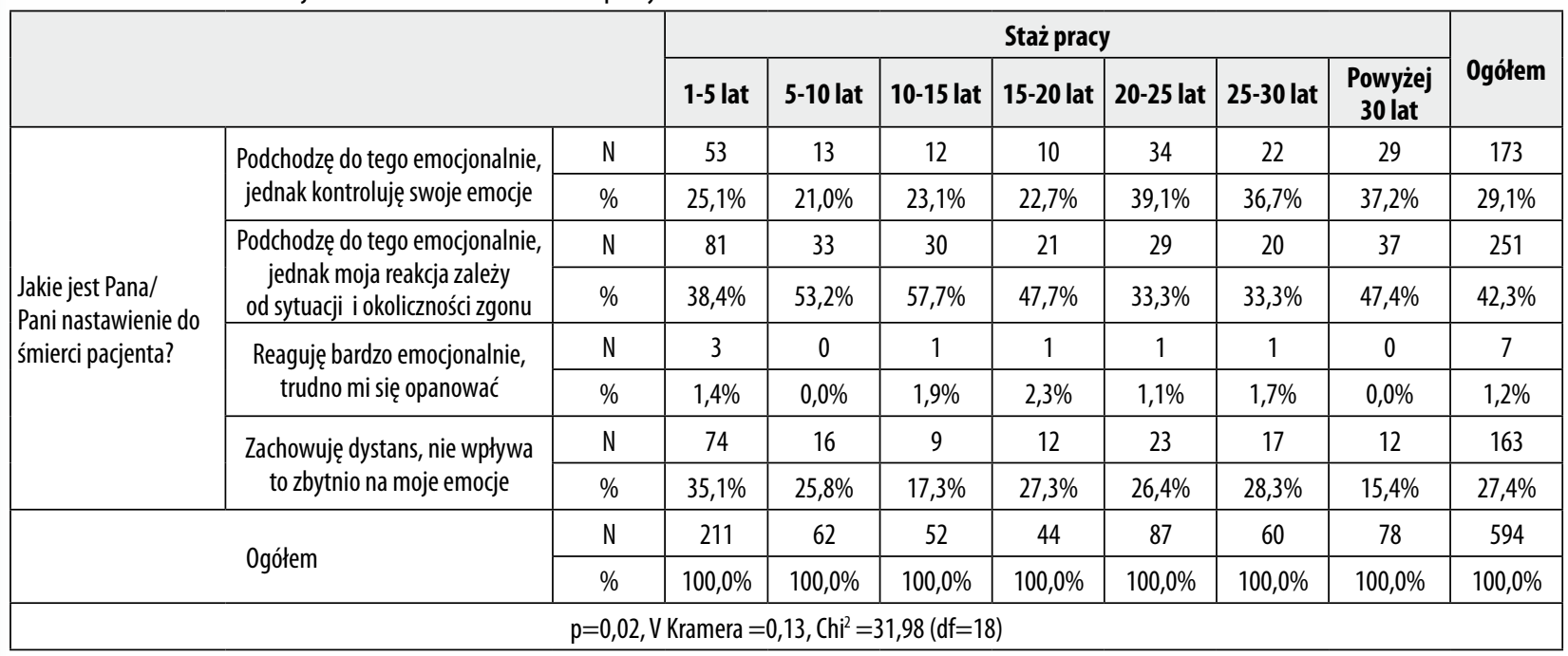




\section{DYSKUSJA}

Aby móc przedstwawić szerzej zagadnienie postaw wobec śmierci najpierw należy wskazać czym tak naprawdę dla osób pracujących w ochronie zdrowia jest śmierć. $\mathrm{W}$ autorskim badaniu największy odsetek badanych pielęgniarek i pielęgniarzy postrzega zjawisko śmierci jako coś naturalnego z czym każdy kiedyś będzie musiał się zmierzyć (52,2\%). Idealnie zdaje się tu pasować maksyma mówiąca: „Śmierć nie jest kresem, lecz odcieniem, modalnościa życia, a życie - odcieniem śmierci”, której autorem jest Jean Baudrillard. W badaniu Krajewskiej-Kułak okazało się, że członkowie zespołów pielęgniarskich podczas kontaktu z umierającym najczęściej akceptują śmierć i traktują ją jako zjawisko naturalne (40,4\%). Zawiślak w swojej pracy pokazała, iż 61\% pielęgniarek myśląc o własnej śmierci cechuje się zrozumieniem i akceptacją

Tab. 4. Nastawienie emocjonalne w zależności od wyznania

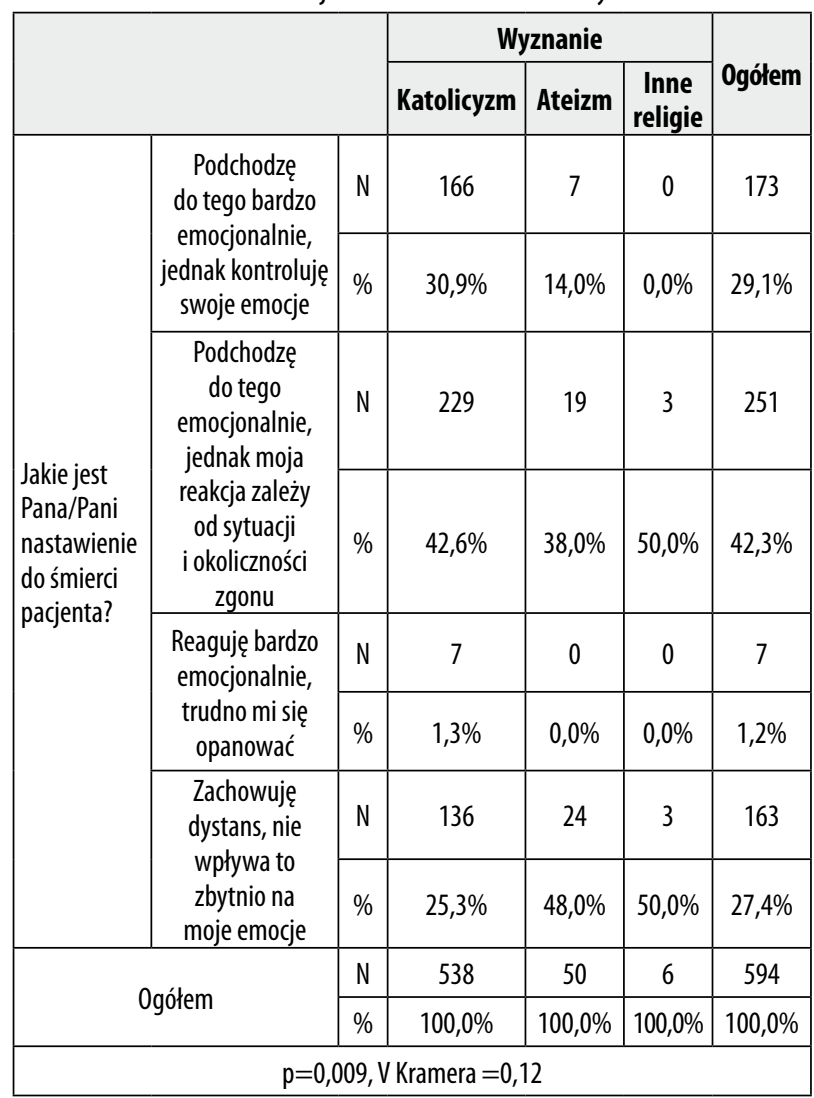

tego nieuchronnego faktu. Miczka-Pajestka w swoich pracach na temat postrzegania śmierci, również dostrzega, iż jest to zjawisko naturalne, które łączy wszystkich ludzi, zarówno tych bogatych jak i biednych, bowiem nikt nie jest w stanie uciec przed śmiercią, wszyscy w końcu "musza się z nia spotkać” $[5,6,7]$.

Śmierć jest zjawiskiem, obok którego nie można przejść obojętnie, które wywołuje u nas określone zachowania.Większość ankietowanych w sposób emocjonalny podchodziło do śmierci pacjentów. Głównymi emocjami powstającymi u członków personelu medycznego podczas opieki nad osobą u kresu jej życia było współczucie $(69,4 \%)$ oraz smutek $(67,8 \%)$. Również w badaniu Ślezionej dominowały osoby, które podchodziły emocjonalnie do śmierci pacjenta ale jednocześnie potrafiły kontrolować te emocje (50,8\%). Ponadto ukazała ona, iż najczęściej śmierci pacjenta podobnie jak w pracy autorskiej towarzyszył smutek (70\%) oraz współczucie (67\%). W badaniu Niedojad stwierdzono, iż najczęstszą reakcją, która towarzyszy personelowi pielęgniarskiemu w sytuacji zgonu pacjenta, jest odczuwanie smutku (82\%). Smutek był dominującym objawem wyzwalanym przy śmierci pacjentów również w badaniu Januszewskiej (71\%). Głowacka analizując śmierć pacjentów jako czynnik obciążenia

\begin{tabular}{|c|c|c|c|c|c|c|}
\hline & & & \multicolumn{3}{|c|}{ Wyznanie } & \multirow[b]{2}{*}{ Ogółem } \\
\hline & & & Katolicyzm & Ateizm & $\begin{array}{c}\text { Inne } \\
\text { religie }\end{array}$ & \\
\hline \multirow{8}{*}{$\begin{array}{l}\text { Jakie jest } \\
\text { Pani/Pana } \\
\text { stanowisko } \\
\text { wobec } \\
\text { eutanazji? }\end{array}$} & \multirow{2}{*}{$\begin{array}{l}\text { Jestem } \\
\text { przeciw }\end{array}$} & $\mathrm{N}$ & 108 & 1 & 1 & 110 \\
\hline & & $\%$ & $20,1 \%$ & $2,0 \%$ & $16,7 \%$ & $18,5 \%$ \\
\hline & \multirow{2}{*}{$\begin{array}{l}\text { Jeśli wiem, } \\
\text { iż dalsze } \\
\text { leczenie nie ma } \\
\text { sensu jestem } \\
\text { przeciwko } \\
\text { utrzymywaniu } \\
\text { sztucznie życia }\end{array}$} & $\mathrm{N}$ & 216 & 27 & 3 & 246 \\
\hline & & $\%$ & $40,1 \%$ & $54,0 \%$ & $50,0 \%$ & $41,4 \%$ \\
\hline & \multirow{2}{*}{$\begin{array}{c}\text { Jestem za, jeśli } \\
\text { chce tego pacjent }\end{array}$} & $\mathrm{N}$ & 107 & 19 & 2 & 128 \\
\hline & & $\%$ & $19,9 \%$ & $38,0 \%$ & $33,3 \%$ & $21,5 \%$ \\
\hline & \multirow{2}{*}{$\begin{array}{l}\text { Nie mam } \\
\text { zdania }\end{array}$} & $\mathrm{N}$ & 107 & 3 & 0 & 110 \\
\hline & & $\%$ & $19,9 \%$ & $6,0 \%$ & $0.0 \%$ & $18,5 \%$ \\
\hline \multirow{2}{*}{\multicolumn{2}{|c|}{ Ogółem }} & $\mathrm{N}$ & 538 & 50 & 6 & 594 \\
\hline & & $\%$ & $100,0 \%$ & $100,0 \%$ & $100,0 \%$ & $100,0 \%$ \\
\hline \multicolumn{7}{|c|}{$\mathrm{p}=0,001, \mathrm{~V}$ Kramera $=0,14$} \\
\hline
\end{tabular}

Tab. 6. Opinia wobec stosowania uporczywej terapii w zależności od wieku

\begin{tabular}{|c|c|c|c|c|c|c|c|c|}
\hline & & & \multicolumn{5}{|c|}{ Wiek } & \multirow{2}{*}{ Ogółem } \\
\hline & & & 22-29 lat & 30-39 lat & $40-49$ lat & 50-59 lat & $60 \mathrm{i}$ więcej & \\
\hline \multirow{6}{*}{$\begin{array}{l}\text { Stosowanie uporczywej } \\
\text { terapii w szpitalu } \\
\text { to wg Pani/Pana }\end{array}$} & \multirow{2}{*}{ Przedłużania cierpienia } & $\mathrm{N}$ & 170 & 92 & 144 & 62 & 5 & 473 \\
\hline & & $\%$ & $82,5 \%$ & $84,4 \%$ & $76,6 \%$ & $76,5 \%$ & $50,0 \%$ & $79,6 \%$ \\
\hline & \multirow{2}{*}{$\begin{array}{c}\text { Przedłużanie życia, zawsze jest } \\
\text { szansa powrotu do zdrowia }\end{array}$} & $\mathrm{N}$ & 16 & 11 & 23 & 11 & 4 & 65 \\
\hline & & $\%$ & $7,8 \%$ & $10,1 \%$ & $12,2 \%$ & $13,6 \%$ & $40,0 \%$ & $10,9 \%$ \\
\hline & \multirow{2}{*}{ Nie mam zdania } & $\mathrm{N}$ & 20 & 6 & 21 & 8 & 1 & 56 \\
\hline & & $\%$ & $9,7 \%$ & $5,5 \%$ & $11,2 \%$ & $9,9 \%$ & $10,0 \%$ & $9,4 \%$ \\
\hline \multirow{2}{*}{\multicolumn{2}{|c|}{ Ogółem }} & $\mathrm{N}$ & 206 & 109 & 188 & 81 & 10 & 594 \\
\hline & & $\%$ & $100,0 \%$ & $100,0 \%$ & $100,0 \%$ & $100,0 \%$ & $100,0 \%$ & $100,0 \%$ \\
\hline \multicolumn{9}{|c|}{$p=0,06$} \\
\hline
\end{tabular}


Tab. 7. Postępowanie z umierającym chorym uważane za najbardziej etyczne w zależności od ukończonej szkoły

\begin{tabular}{|c|c|c|c|c|c|c|c|}
\hline & & & \multicolumn{4}{|c|}{ Rodzaj ukończonej szkoły } & \multirow{2}{*}{ Ogółem } \\
\hline & & & Liceum medyczne & Szkoła policealna & Licencjat & Studia magisterskie & \\
\hline \multirow{6}{*}{$\begin{array}{l}\text { Jakie Pani/Pana zdaniem jest } \\
\text { najbardziej etyczne postępowanie } \\
\text { z umierającym pacjentem w stanie } \\
\text { terminalnym? }\end{array}$} & \multirow{2}{*}{$\begin{array}{c}\text { Zapewnić mu godne } \\
\text { warunki umierania }\end{array}$} & $\mathrm{N}$ & 46 & 37 & 267 & 232 & 582 \\
\hline & & $\%$ & $92,0 \%$ & $97,4 \%$ & $98,2 \%$ & $99,1 \%$ & $98,0 \%$ \\
\hline & \multirow{2}{*}{$\begin{array}{l}\text { Stosować wszelkie środki, w celu } \\
\text { podtrzymania i ratowania życia }\end{array}$} & $\mathrm{N}$ & 4 & 1 & 3 & 1 & 9 \\
\hline & & $\%$ & $8,0 \%$ & $2,6 \%$ & $1,1 \%$ & $0,4 \%$ & $1,5 \%$ \\
\hline & \multirow{2}{*}{ Nie mam zdania } & $\mathrm{N}$ & 0 & 0 & 2 & 1 & 3 \\
\hline & & $\%$ & $0,0 \%$ & $0,0 \%$ & $0,7 \%$ & $0,4 \%$ & $0,5 \%$ \\
\hline \multirow{2}{*}{\multicolumn{2}{|c|}{ Ogółem }} & $\mathrm{N}$ & 50 & 38 & 272 & 234 & 594 \\
\hline & & $\%$ & $100,0 \%$ & $100,0 \%$ & $100,0 \%$ & $100,0 \%$ & $100,0 \%$ \\
\hline \multicolumn{8}{|c|}{$\mathrm{p}=0,008$, V Kramera $=0,12, \mathrm{Chi}^{2}=7,30(\mathrm{df}=6)$} \\
\hline
\end{tabular}

Tab. 8. Postępowanie z umierającym chorym uważane za najbardziej etyczne w zależności od wieku ankietowanych

\begin{tabular}{|c|c|c|c|c|c|c|c|c|}
\hline & & & & & Wiek & & & Onćlnm \\
\hline & & & 22-29 lat & $30-39$ lat & 40-49 lat & 50-59 lat & $60 \mathrm{i}$ więcej & Oguiein \\
\hline & Zapewnić mu godne & $\mathrm{N}$ & 201 & 108 & 185 & 80 & 8 & 582 \\
\hline Jakie Pani/Pana & warunki umierania & $\%$ & $97,6 \%$ & $99,1 \%$ & $98,4 \%$ & $98,8 \%$ & $80,0 \%$ & $98,0 \%$ \\
\hline zdaniem jest najbardziej & Stosować wszelkie środki, w celu & $\mathrm{N}$ & 3 & 1 & 2 & 1 & 2 & 9 \\
\hline z umierającym pacjentem & podtrzymania i ratowania życia & $\%$ & $1,5 \%$ & $0,9 \%$ & $1,1 \%$ & $1,2 \%$ & $20,0 \%$ & $1,5 \%$ \\
\hline w stanie terminalnym? & Nliomom zdrni & $\mathrm{N}$ & 2 & 0 & 1 & 0 & 0 & 3 \\
\hline & 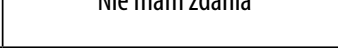 & $\%$ & $1,0 \%$ & $0,0 \%$ & $0,5 \%$ & $0,0 \%$ & $0,0 \%$ & $0,5 \%$ \\
\hline & Orólon & $\mathrm{N}$ & 206 & 109 & 188 & 81 & 10 & 594 \\
\hline & (1) & $\%$ & $100,0 \%$ & $100,0 \%$ & $100,0 \%$ & $100,0 \%$ & $100,0 \%$ & $100,0 \%$ \\
\hline
\end{tabular}

w pracy zawodowej personelu pielęgniarskiego pokazała, iż najczęściej w przypadku śmierci pacjenta odczuwany jest smutek (82,7\%) i współczucie (74\%). Badanie Ek zrealizowane wśród studentów pielęgniarstwa wykazało, iż najczęstszymi pojawiającymi się emocjami przy śmierci chorych był smutek, bezbronność i bezradność związana $\mathrm{z}$ małym doświadczeniem w zawodzie $[8,9,10,11,12]$.

Badanie własne wskazało, iż w dużej mierze natężenie powstałych emocji uzależnione jest od sytuacji i okoliczności zgonu. Przeprowadzona analiza wykazała, iż większe emocje występują u personelu pielęgniarskiego w przypadku śmierci młodszych osób $(82,3 \%)$ oraz gdy do śmierci dochodzi nagle (76,9\%). Potwierdzenie dla osiągniętych wyników odnajdujemy u Ślezionej, gdzie 51\% badanych największe emocje odczuwało, gdy dochodziło do śmierci dziecka. Niedojad w prowadzonych analizach statystycznych ukazała, iż głównymi czynnikami, które mają wpływ na zachowanie personelu pielęgniarskiego w obliczu umierania i śmierci, są wiek chorego (98\%) oraz nagły, niespodziewany zgon (97\%). Ponadto Zawiślak w swojej pracy pokazuje, iż najwięcej uczuć pejoratywnych powstaje na skutek śmierci dziecka. Założoną hipotezę potwierdzają również zagraniczne badania. Fitch badając grupę zawodową pielęgniarek i pielęgniarzy odkrył, iż bardziej emocjonalnie podchodzą do śmierci młodych osób, gdyż uważają, że „nie mieli oni czasu na zrealizowanie swojego potencjału”, największe emocje budziła śmierć dziecka. Wilson ankietując cały zespół terapeutyczny zaobserwował, iż szczególnie trudna dla nich była śmierć pacjentów w ich wieku i młodszych od nich $[7,8,9,13,14]$.
Autorskie badanie ukazało, iż kwestią sporną pozostaje nadal możliwość zastosowania eutanazji, lecz w wielu przypadkach dopuszczalne staje się odejście od uporczywej terapii w sytuacjach, gdy rokowanie nie daje pacjentowi szans na przeżycie $(41,4 \%)$ lub gdy chory sam prosi o rezygnację z podejmowania daremnych prób ratowania jego życia $(21,5 \%)$. Wart zaznaczenia jest również fakt, iż uporczywa terapia w oczach pielęgniarek i pielęgniarzy postrzegana jest głównie jako przedłużanie jego cierpienia pacjenta $(79,6 \%)$. Fakt, iż wyrażanie aprobaty na stosowanie eutanazji jest kwestią kontrowersyjną możemy zaobserwować w analizach Mickiewicz, gdzie eutanazję akceptowało $42 \%$ badanych natomiast $40 \%$ dokonywało jej dezaprobaty. W prowadzonych na świecie badaniach obserwuje się bardzo interesującą zależność dotyczącą akceptacji eutanazji w różnych krajach, w Niemczech wynosiła ona $82 \%$, w Stanach Zjednoczonych 80\%, w Kanadzie 76\%, w Szwecji $61 \%$, natomiast w Polsce $42 \%$. Mickiewicz wykazała również, iż 48,9\% pracujących w zawodzie pielęgniarek i pielęgniarzy jest za odłączeniem aparatury sztucznie podtrzymującej życie jeśli pacjent nie rokuje na polepszenie stanu zdrowia $[15,16]$.

Prowadzone badania pokazały, iż zdaniem pielęgniarek i pielęgniarzy najbardziej etycznym postępowaniem wobec osoby w stanie terminalnym jest zapewnienie mu godnych warunków umierania (98\%). Śleziona w swoich analizach ukazała, iż 70,8\% pielęgniarek i pielęgniarzy za najważniejsze przy umieraniu chorych uważa okazywanie pełnej szacunku postawy oraz wykazywanie się empatią 
podczas wykonywaniu przy chorym czynności pielęgniarskich. W badaniu prowadzonym przez Kurleto-Kalitowską pielęgniarki uważały, iż w przypadku pacjentów terminalnie chorych należy im zapewnić przede wszystkim opiekę pielęgniarską (42,5\%), zaprzestać uporczywej terapii $(40 \%)$ oraz stosować tylko leczenie przeciwbólowe $(37,5 \%)$. Ponadto $80 \%$ respondentek było zdania, iż gdyby one miały podejmować decyzje w sprawie dalszego postępowania $\mathrm{z}$ terminalnie chorymi to zdecydowałyby o zrezygnowaniu z kontynuowania uporczywej terapii. Rui-Shuang prowadzący badania wśród chińskiego personelu medycznego, podkreślał że najważniejsze przy postępowaniu $\mathrm{z}$ chorym $\mathrm{w}$ terminalnym stanie jest podejmowanie opieki pielęgniarskiej oraz uśmierzanie bólu $[8$, $17,18]$.

Badani członkowie zespołów pielęgniarskich $\mathrm{w}$ większości uważają, iż do śmierci pacjenta nie można się przyzwyczaić (34,3\%), a część $z$ nich przyzwyczajenie się do śmierci uważa za jednoznaczne $\mathrm{z}$ wypaleniem zawodowym (23\%). Jeszcze wyższy wynik osiągnięto $\mathrm{w}$ pracy badawczej Januszewskiej, gdzie $68 \%$ pracowników ochrony zdrowia uważa, że nie można się przyzwyczaić do śmierci pacjentów. W swoich badaniach Śleziona osiągnęła niższy poziom przeczących odpowiedzi $(33,4 \%)$, jednak w badaniu użyła ona sformułowania „uodpornić" zamiast „przyzwyczaić”. W jej badaniu również zauważalny jest odsetek osób twierdzących, iż uodpornienie na śmierć to już wypalenie zawodowe (14,2\%). Natomiast w badaniu Marcysiak codzienny kontakt ze śmiercią pacjenta był trzecim najczęstszym czynnikiem powodującym stres w pracy pielęgniarskiej $(62 \%)[8,10,19]$.

\section{WNIOSKI}

1. Śmierć postrzegana jest przez pielęgniarki i pielęgniarzy jako zjawisko naturalne, z którym każdy kiedyś będzie musiał się zmierzyć.

2. Śmierć dla personelu pielęgniarskiego jest zjawiskiem, wywołującym powstawanie wielu negatywnych emocji, wśród których dominuje smutek i współczucie. Wraz ze wzrostem stażu pracy oraz wiekiem pielęgniarek i pielęgniarzy częściej pojawia się smutek.

3. Głównymi czynnikami determinującymi natężenie emocji przy śmierci pacjentów jest wiek chorego oraz rodzaj zgonu. Więcej emocji powoduje śmierć młodszych osób oraz gdy do śmierci dochodzi nagle.

4. Aprobata dokonania eutanazji pozostaje nadal kwestią sporną, jednak coraz większy odsetek pracujących w zawodach medycznych dopuszcza zaprzestanie uporczywej terapii. Na możliwość stosowania eutanazji częściej wskazują ateiści.

5. Najbardziej etycznym postępowaniem wobec pacjenta umierającego w opinii zespołu pielęgniarskiego jest zapewnienie mu warunków godnej śmierć. To przekonanie rośnie wraz z posiadanym wykształceniem.

6. Do śmierci pacjenta nie można się przyzwyczaić, a przejawy takich zachowań są postrzegane jako objawy wypalenia zawodowego.

\section{REFERENCES/PIŚMIENNICTWO}

1. Major M, Ulman P. Charakterystyka wybranych postaw społecznych w Polsce. Analiza statystyczna. Uniwersytet Ekonomiczny w Krakowie. Zeszyty Naukowe 2011; 847: 5-23.

2. Becler R. Ewolucja operacyjnej definicji śmierci człowieka. Prawo i Medycyna. 2015; 2(59): 17, 52-59.

3. Dangel T, Murawska M, Marciniak W. Pediatryczna domowa opieka paliatywna w Polsce. Medycyna Paliatywna. 2010; 3: 136-138.

4. Sagan M, Pakosz A, Janecki M. Rola opieki paliatywnej w okresie żałoby i osierocenia. Medycyna Paliatywna. 2010; 2,3: 132-136.

5. Miczka-Pajestka M. Śmierć, która nie chce być zobrazowana...? Kulturowe uwarunkowania myślenia 0 śmierci i śmiertelności a ponowoczesna wizja śmierci. Transformacje. 2016; 1-2 (88-89): 60-72.

6. Krajewska-Kułak E, Mickiewicz I, ŁukaszukC, i wsp. Samoocena postaw pielęgniarek wobec śmierci. Pielęgniarstwo XXI wieku. 2010; 1-2: 43-49.

7. Zawiślak A. Postawy pielęgniarek hospicyjnych wobec śmierci własnej i bliskich osób. Pielęgniarstwo i Zdrowie Publiczne. 2016: 6(3): 197-203.

8. Śleziona M, Krzyżanowski D. Postawy pielęgniarek wobec umierania i śmierci pacjenta. Pielęgniarstwo i Zdrowie Publiczne. 2011: 1(3): 217-223.

9. Niedojad K, Rybka M, Rezmerska L, Ślusarz R. Śmierć i umieranie w opinii personelu pielęgniarskiego. Pielęgniarstwo w 0piece Długoterminowej. 2016; 3: 12-18.

10. Januszewska A, Zarzeka A, Iwanow L, i wsp. Próba analizy poziomu wiedzy i postaw pracowników Kliniki Intensywnej Terapii Instytutu „Pomnika - Centrum Zdrowia Dziecka" wobec prowadzenia uporczywej terapii u dzieci. Pielęgniarstwo Polskie. 2016; 3(61): 389-395.

11. Głowacka M, Haor B, Ślusarz R, i wsp. Śmierć pacjenta jako obciążenie w pracy zawodowej pielęgniarki. Problemy Pielęgniarstwa. 2014; 22(2): 276-280.

12. Ek K, Westin L, Prahl C, et al. Death and caring for dying patients: exploring firstyear nursing students' descriptive experiences. International Journal of Palliative Nursing. 2014; 20(10): 510-515.

13. Fitch M. Understanding Oncology Nurses. Experiences Talking About Death and Dying. Toronto, Canada. 2014; s. 10-11.

14. Wilson J, Kirshbaum M. Effects of Patient Death on Nursing Staff: A literature review. Sheffield Hallam University Research Archive. 2011; 6-12.

15. Mickiewicz I, Krajewska-Kułak E, Kędziora-Kornatowska K, Rosłan K. Postawy pielęgniarek wobec eutanazji. Pielęgniarstwo i Zdrowie Publiczne. 2011; 1(3): 199-208.

16. Szymańska K. Postawy wobec eutanazji wśród studentów pielęgniarstwa, prawa i kleryków. Pielęgniarstwo i Zdrowie Publiczne. 2012; 2(2): 125-133.

17. Kurleto-Kalitowska E, Romanowska U, Lipińska M, Maj K. Postawy pielęgniarek wobec stosowania uporczywej terapii. Interdyscyplinarne aspekty nauk o zdrowiu. Wyd. Krakowskie Towarzystwo Edukacyjne. 2010; s.155-168.

18. Rui-Shuang Z, Qiao-Hong G, Feng-Qi D, Glynn 0. Chinese oncology nurses' experience on caring for dyingpatients who are on their final days: A qualitative study. International Journal of Nursing Studies. 2015; 52: 288-296.

19. Marcysiak M, Szczepańska E, Ostrowska B, Marcysiak M. Zagrożenie wypaleniem zawodowym wśród pielęgniarek pracujących z terminalnie chorymi. Pielęgniarstwo w Opiece Długoterminowej. 2016; 1, s. 28-37.

Manuscript received/Praca zgłoszona do czasopisma: 10.03.2019

Manuscript accepted/Praca zaakceptowana do druku: 17.06.2019

Translation/Tłumaczenie: Natalia Makowicz 